\title{
TAFSIR AL-QUR'AN DI MEDSOS: Nadirsyah Hosen's Resistance to the Politicization of the Quran in Indonesian Social Media
}

\author{
Ridho Agung Juwantara, Rezki Putri Nur Aini, and Dwi Noviatul Zahra \\ Universitas Islam Negeri Raden Intan Lampung, Indonesia \\ E-mail: ridhoaj57@gmail.com
}

\section{Abstract}

This article aims to examine a book of Nadirsyah Hosen, an Indonesian diaspora in Australia, entitled Tafsir Al-Qur'an di Medsos. Hosen's interpretation of the Quran is interesting because it is directly related to the actual political context in Indonesia. This study uses a descriptive analysis approach, making the book Tafsir Al-Qur'an di Medsos as the primary source and a number of other books, journals and credible news portals as the secondary sources. By taking five examples of Hosen's interpretation, namely religious freedom, non-Muslim leadership, the terminology of kafir, the KPU (Komisi Pemilihan Umum) verse, and the caliphate issue, this study finds that Hosen's interpretation is a form of resistance to the dynamics and phenomena of contemporary Muslim diversity, especially in the Indonesian context. He interpreted the Quran in response to the politicization of the scripture through social media platforms, especially in relation to the political situation in Indonesia. He attempts to advocate the relience on credible literature when doing tafsir and that the verses of the Quran must be understood in a proper context. For example, in addressing the labelling of kâfir and kâfir leadership issue, he suggests that one cannot use it as an excuse to not choosing leaders from non-Muslims because Allah does not forbid Muslims to do good to nonMuslims according to al-Mumtahanah [60]: 8. He also identifies inaccuracy of accociating al-Nisấ' [4]: 108 with the KPU, because the revelation of the 
verse indicates the Quranic defense of an innocent Jew who trapped in a conspiracy from a Muslim.

Artikel ini bertujuan untuk mengkaji buku "Tafsir Al-Qur'an di Medsos" karangan Nadirsyah Hosen, salah seorang intelektual Indonesia yang berdomisili di Australia. Penafsiran Al-Qur'an yang dilakukan oleh Hosen di dalamnya sangat menarik karena berkaitan langsung dengan konteks politik di Indonesia yang aktual. Kajian ini menggunakan pendekatan deskriptifanalitis dari buku Tafsir Al-Qur'an di Medsos sebagai data primer, serta sejumlah buku, jurnal, dan portal berita yang kredibel sebagai data sekunder. Dengan mengambil lima contoh penafsiran Hosen, yaitu mengenai kebebasan beragama, pemimpin kafir, terminologi kafir, ayat KPU (Komisi Pemilihan Umum), dan ide khilafah, penulis menemukan bahwa tafsir yang dilakukan Hosen merupakan salah satu bentuk resistensi terhadap dinamika dan fenomena keberagamaan umat Islam kontemporer, terutama dalam konteks Indonesia. Ia melakukan penafsiran terhadap ayat-ayat Al-Qur'an dalam rangka menolak politisasi ayat Al-Qur'an melalui platform media sosial, khususnya dikaitkan dengan situasi politik Indonesia. Ia berupaya meneguhkan bahwa kajian tafsir harus merujuk pada literatur yang kredibel dan ayat Al-Qur'an harus dipahami secara kontekstual yang tepat. Misalnya, bagi Hosen, dalam menyikapi pelabelan kafir dan pemimpin kafir, ayat yang dipolitisasi belum bisa dijadikan alasan untuk tidak boleh memilih pemimpin dari non muslim karena Allah tidak pernah melarang umat Islam untuk berbuat baik pada non muslim sesuai dengan al-Mumtahanah [60]: 8. Begitu pula mengenai ketidakakuratan kontekstualisasi tafsir surat al-Nisâ' [4]: 108 yang dikaitkan dengan masalah KPU, karena sebab turunnya ayat saat itu justru mengindikasikan pembelaan Al-Qur'an terhadap seorang Yahudi yang tidak bersalah dan terjebak konspirasi dari seorang Muslim.

Keywords: Nadirsyah Hosen; new media; politicization of verses; Tafsir AlQur'an di Medsos

Received: August 25, 2020; Accepted: December 22, 2020

\section{Introduction}

A few years ago, the political situation in Indonesia was widely discussed, whether through print, electronic or social media. This situation would naturally grow intense following the election period. Political parties 
would employ all methods possible to support their candidates, both in regional and national level, started from making all size of banners and advertisements depicting each candidate and the way to vote them. At this context, one of the most crucial and complex issues is politicization of the Quran with the aim of winning public sympathy and support. Not only does the politicization of the Quran influence public political preference, it has also brought about public division and overwhelmed disputes especially among Muslims (Hosen 2019b).

According to Dale Canon, as quoted by Ahmad, there are six (6) forms of community expressions in religion, ie. rite, rational, ascetic, supernatural, sufistic, and praxis. This classifications reflects the levels of expression of society in understanding religion (Achmad 2018, 142). It explains that the people who exclusively express their religion through rites will completely ignore rationality because they are unable to fully and comprehensively understand religion, and as a consequence, religious fundamentalism rises. This phenomenon has caused unrest among Islamic scholars because they feel that illegitimate Quran interpretation would have detrimental consequences in the future, especially among the Muslim community.

Nadirsyah Hosen, or otherwise Gus Nadir, is one of the progressive scholars react against the politicization of the Quran by irresponsible parties. $\mathrm{He}$ is a scholar and lecturer who has long been active in the world of academia in Australia. He frankly responded to the phenomenon of political upheaval in Indonesia during the 2017 DKI Jakarta Regional Election (Hosen 2019b). As a technologically literate figure and a lecturer interacting widely with students, Hosen understands how information can quickly spread through the various platforms exist today, especially social media, which is now an easy platform in which one can instill certain ideas and influences. According to him, social media, without doubt, has positive impacts; but that does not mean that it does not have negative effects. Precisely with social media, people no longer critically filter the information conveyed (Hosen 2019a). This then encouraged Hosen to fulfill his moral responsibility as a Muslim trained with Islamic intellectual legacy. It was answering to this developments he wrote Tafsir Al-Qur'an di Medsos (Quranic Exegesis on Social Media), in which he offers earlier scholars views on the selection of verses and then provides his personal view at the end of each discussion. 
Not only describing political verses, the contents of the book Tafsir AlQur'an di Medsos indeed represent the situation of today's society in general. Each chapter explains itself briefly and uses the language that is readable for both specialists and non-specialists. This article takes the focus of Hosen's logically and clearly presented discussions regarding political verses in the book for it is considered sufficient to add insights and therefore is necessary to be disseminated to the wider communities who previously did not know about the "political trickeries". Even though this book was just recently published, it does not mean that no one has tried to further examine it. There are some works discussing the contents of the book using various methods and perspectives. Although not many, it is a proof that his writings and thoughts provoke scholarly interest by academics.

The politicization of the Quran is a prevalent practice in the history of Islamic civilization. Hosen suggests that this practice is a consequence of the existing affairs between power and religion. In other words, the politicization of the Quran is a particular manifestation of the politicization of religion. Currently, politicization of the Quran becomes even easier to conduct in the era of social media because of its practicality beyond time and space. Social media makes everyone an interpreter regardless the necessary competence. This intensity transcends the gender boundaries that were familiar with the hermeneutic world of the Quran.

The history of Islam proves the strong dominance of men commentators, proven by a study of Johanna Pink surveying contemporary commentaries from Muslim-majority countries such as the Arab world, Turkey, and Indonesia (Pink 2010). Social media, stated by Noor Achmad in his writing entitled "The Politization of Religion in the Digital Age and Its Handling," triggers for disruption, especially in religion (Achmad 2018, 141). This disruption resulted in a shift in the way people learn and understand religion. Today's religious understanding is formed from a click in the internet through 'social media scholars', both authoritative and not. Ordinary people who do not have the proper religious literacy will easily follow the teachings found in the social media without being able to assess right or wrong. This opportunity is an opportunity for politicians under the guise of religion with deviant goals.

The results of Saifullah's thesis actually say that the more people use social media because of its sophistication, the more likely it is to open people's minds to stem the negative effects of disruption. However, it must be grounded and understood in a more detail interpretation to be shared on 
social media (Saifullah 2019). In his thesis, he also analyses the relevance of Quranic hermeneutics juxtaposed with the use of social media.

Muzakka conducted research on Hosen from a different perspective, where he compared the way of conveying opinions between Hosen and Firanda Adirja through their respective social media accounts (Muzakka 2018). He tries to find different methods and scientific colors in explaining each of his studies, including how current issues affect the way of thinking of both of them to be analyzed according to the references believed by the two clerical figures before finally being conveyed to the people.

Apart from Hosen's reaction towards the politicization of religion, the politicization of the Quran has been subject to wide range of scholarly encounters. The political verse, in this context, is defined as a set of verses that contain political interpretation advocating for the particular attitudes, behaviour and social policies that are closer to certain interests, the benefit of humans, as well as keeping away from adversity by providing direction and a way to save them in this world and the hereafter (Mahfudh 1994, 209-10).

Because the practice of religious politicization is a result of the relationship between politics and religion, Gin came up with his writing entitled Jesus Q. Politician: Explaining the Politicization of Religion in the United States, Australia, and Canada by focusing on three countries known to be secular, namely United States, Australia and Canada. Cited from David C. Leege and Lymann A. Kellstedt, Gin chose the three countries to prove what some people have believed regarding the denial of religion in a secular society is not entirely true. He concluded that despite being known as a secular state, those three countries often indicated a mutually sustainable role between politics and religion. Moreover, he found that Catholic groups also use religious elements to get legitimacy from their political role in the government (Leege and Kellstedt 1993, 3-4). This statement was later confirmed by David and Lymann, suggesting that the political constellation in the United States in the lead-up to the presidential election of Barack Obama and his rival Hillary Clinton was also marked by the intrigue of using religion in politics as an image aimed at getting sympathy and public interest from each candidate.

In contrast, Ogunto shows that the elements of politics and religion in a country are necessities that are harmonious because both are in need of each other. In Nigeria, his case study, the political elites used religion as an important element in the government and with it, they are evidently able to 
run the governance effectively, even though at the end, the freedom of its implementation is limited to those playing the role in it (Ogunto 2008, 123). His earlier study, Onapajo observed the close relationship between politics and religion in Nigeria where the role of religion is one of the determining factors for the formation of policies in the Nigerian government (Onapajo 2012, 42-50). Some circles consider religion as the trigger of conflicts, but Onapajo argues that the ability of religion to resolve conflicts has a greater influence than as a trigger (Onapajo 2012, 57-58). This phenomenon occurs because public fanaticism in Nigeria towards religion is more dominant than the belief in the government.

These studies on the politicization of religion, especially that aimed at winning public confidence, show that it is not a recently growing practice and does not happen exclusively to Islam but also other religions. This practice happens because even though the era has changed, people still have the interest in religious and syncretic matters. Social media, in fact, makes it easier for these goals to be achieved. At this point, this study maps the significance of the research focus on these previous studies. Although it also deals with the issue of the relationship and religion's role in politics, the core focus of this study is Nadirsyah Hosen's commentary book. We will explain more specifically how and when these political verses going viral in social media platforms, to the extent that they became the jargon in every campaign moment through the recent political development in Indonesia, especially ahead of the 2019 simultaneous elections to this day. The purpose of this research is to enlighten people, especially those who remain trapped in fanaticism towards the certain candidates for religious credential, because the appropriation of the Quranic verses for supporting particular candidates, more often than not, causes conflicts among supporters of other candidates.

The argument built in this study is that social media is increasingly giving a significant influence in all lines of life, especially the political participation of the Indonesian people in enlivening the five-yearly election. The certain elites take advantage of this moment both to win public confidence and to delegitimize their political opponents. Appropriating the Quranic verses has been considered as one of effective ways to materialise this interest. It becomes effective because Indonesian societies are experiencing conservative turn and the rapid growth of social media is feared to cause misinterpretations that have an impact on public peace. 
Accordingly, this article tries to push the direction of people's mind maps back into the right direction.

To obtain the detailed and comprehensive results and discussion, this study uses a contextual interpretation method with a qualitative descriptive analysis approach. This strategy is used to achieve the accurate findings consistent with the context of the verses. This article also carries out literature research towards several sources, both primary and secondary. Tafsir Al-Qur'an di Medsos is the primary source, whereas the secondary sources include journal articles, the other supporting books, and the credible news portals available on electronic and social media.

In doing so, this article classifies and explains the relevant verses coherently based on the period of the political incidents using a contextual manner, taking into consideration the occasion of revelation of the respective verse and contextualization through the phenomenon of Indonesian politics, especially during elections.

\section{The Impact of New Media on Shifting Socio-Religious Phenomena}

When viewed from what is the basis of Manuel Castells' view, where he deliberately gives more portions to the development of new media, in this case social media and the like, the emergence of this new media has a significant influence on all parties, especially people in a particular country. He also suggests that new media does not define society, but creates society. It is the community who shapes the new media according to the needs, values and interests of other people who use it. Even clearly, he also did not deny the existence of this form of information society which resulted in wealth, strength, and the generation of knowledge depending on the ability to organize other societies and reap the benefits of using the new media (Castells and Cardoso 2005, 3). This understanding is in line with what happens in Indonesian society where they started gradually; even most of them have metamorphosed into an information society and formed a network society (Dawson and Cowan 2004; Kietzmann et al. 2011; Krysinska, Andriessen, and Corveleyn 2014; Miski and Hamdan 2019; Rifauddin 2016).

On the other hand, the information society that occurs in Indonesia is a gateway to bridge the entry of globalization of piety that, according to Turner, is a form of modern religion and the product of globalization, where the main purpose of religion is no longer confined to syncretic and sacred matters but has jumped far on the global capital circuit that has been 
successfully converted into a lifestyle to become an institution that is able to offer satisfying commodities and services to its consumers (Turner 2011). Now, the globalization of piety in Indonesia has been applied in the form of devout characters and icons that look massive through social media (online) such as YouTube, Twitter, and Instagram. In their development, these three virtual-based applications are the main media that have become the 'soft tool' for the owners of online media accounts which in fact is very influential in the provision of content to its presentation to consumers. Instead of making the application just a distraction without serious meaning, it is evident that many consumers who are interested in da'wah might find inspiration from the information and opinions of certain thoughts and ideas in it (Hakim 2013; Ali, Purwandi, and Firmansyah 2015; Lengauer 2018; Mulawarman and Nurfitri 2017; Omar et al. 2015; Pradana and Yuliati 2015; Sharifian et al. 2017; Slama 2018).

Globalization of piety which is getting stronger in this new media era proves that the influence of religiosity appears after a long time being hegemonized by secular and liberal currents. It has even been claimed as the plenary ideology of world society by Francis Fukuyama in his thesis entitled "The End of History". This indicates that the existence of Islamism has begun to appear stronger; Islamism interprets all non-Muslim circles as kuffâr (infidels) and is considered an enemy of Islam. They are also very much targeting liberal Muslim thinkers. The threat of cruel Islamism makes it unnecessary and even tends to be avoided in Islamic civilization (Kholiludin 2016). Accordingly, Tibi deeply regrets and criticizes those circles, who are politicizing religion. According to him, Islam as a system of belief is different from Islamism, which is a category of religious politics. Islamism is a political interpretation of Islam which has absolutely nothing to do with belief. However, its domain is the ideological application of religion in the political realm and then forms a state which he calls Religionized Politics and becomes a significant example of the global phenomenon of religious fundamentalism (Tibi 2012, 1; 2016, 1). According to him, this is very contradictory and dangerous for Islam itself.

Castells' view of the formation of a network society today was proven when he tried to analyze the situation of Indonesian society. This is supported by the data from the official Kominfo (Ministry of Communication and Informatics) website displaying an increase in the intensity of social media use by Indonesian people. It creates a very high risk of spreading 
negative content as well as messages of provocation and hate speech leading to conflict (Kominfo 2018).

\section{Figure 1}

Increasing Global Usage

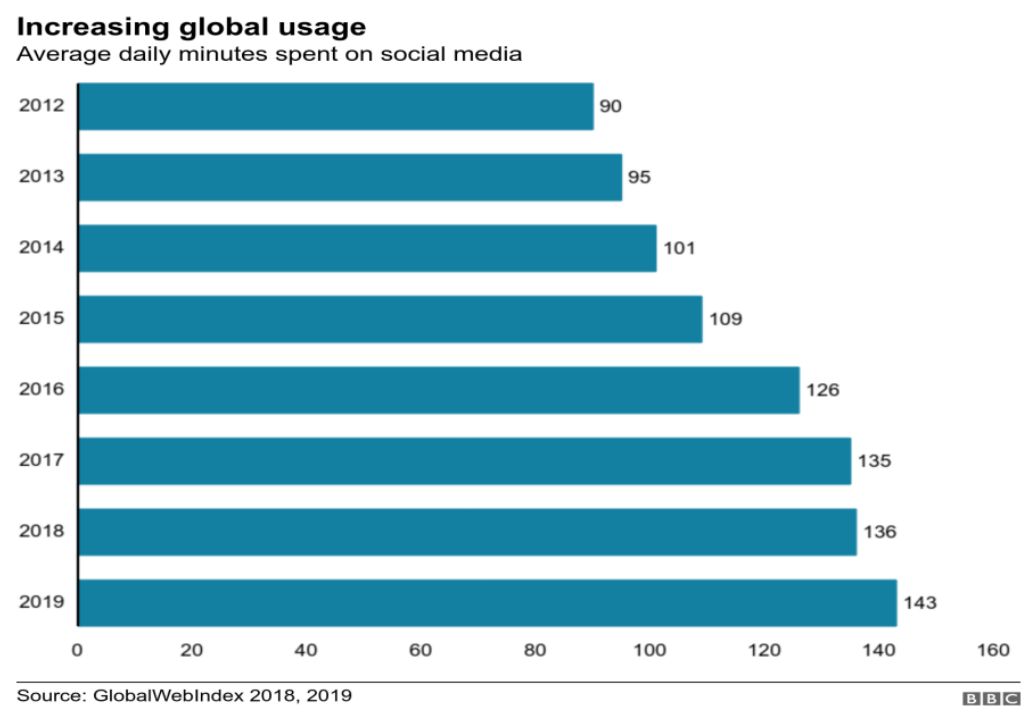

In fact, one of the BBC's verified news portals also strengthens Kominfo's data by providing quantitative facts in classifying countries who are the most active and the longest users of social media within 24 hours. 
Figure 2

The most "social" countries

\begin{tabular}{|c|c|c|c|}
\hline Ranking & Country & Minutes (2019) & Minutes (2018) \\
\hline 1 & Philippines & 241 & 248 \\
\hline 2 & Brazil & 225 & 219 \\
\hline 3 & Colombia & 216 & 214 \\
\hline 4 & Nigeria & 216 & 206 \\
\hline 5 & Argentina & 207 & 197 \\
\hline 6 & Indonesia & 195 & 203 \\
\hline 7 & UAE & 191 & 180 \\
\hline 8 & Mexico & 190 & 194 \\
\hline 9 & South Africa & 190 & 178 \\
\hline 10 & Egypt & 186 & 185 \\
\hline 12 & Saudi Arabia & 186 & 172 \\
\hline 13 & Turkey & 185 & 172 \\
\hline 18 & Russia & 148 & 141 \\
\hline 19 & India & 145 & 148 \\
\hline 22 & China & 139 & 120 \\
\hline 25 & US & 117 & 125 \\
\hline
\end{tabular}

In the figure 2, Indonesia is ranked 6th in the country that spends the most time online every day (Duarte 2019). These data show the activeness of Indonesian people in using social media which is increasing every day. It points to the establishment of the information society, even if they do not realize it.

The significance of the formation of information society is not limited to the use of social media. It also includes the impact it produces, that is where the people are currently shifting from consumers to producers of information (Miladi 2016, 48). This is evident in the current era where people are starting to be involved in the social, economic and even political fields, even though not directly. The ordinary people who does not have the necessary capital but have an interest of involving in the social, economic, and political movements would become 'behind the scenes actors,' employing social media intermediaries to accommodate their interests. This in turn has various kinds of impacts, both positive and negative, because the 
existence of social media obscures the viewpoint of who the consumers and producers are (Zuhri, Noor, and Miski 2018).

Islamist figures who have appeared in the last few decades and have coloured the social, economic and political life of the Indonesian people also seem to not want to be left behind in the use of social media. In addition, the Indonesian Muslim community's interest in pious figures is also getting stronger. This provides a golden opportunity for the users of Islamic da'wah accounts, either on YouTube, Twitter and Instagram, all of which seem to flock to each other to present religious content with all kinds of purposes (Imron 2019; Miski 2017).

Social media is usually considered merely as entertainment. It, however, increasingly becomes an instrument of education and information gateway, especially on da'wah accounts. Instead of making the mobile application just a distraction without serious meaning, it is evident that many users take advantage from $d a$ 'wah material provided in them.

Often these radical Islamists make claims of justification for any political statements. They do not hesitate to take advantage of the holy verses of the Quran to perpetuate their purpose as legitimacy that their statement is absolute. This kind of textual engagement with the Quran has become subject to criticism from some tafsir scholars, for they see that it is not that easy to place a certain Quranic verse and link it to the contemporary political development without knowing and exploring the occasion of the revelation of the verse (Muhtador 2018). Against this backdrop, in the next section, this study will describe the political verses raised by Nadirsyah Hosen in his book, Tafsir Al-Qur'an di Medsos and their contextualization through the recent Indonesian political phenomenon.

\section{Prompts for Upholding Religious Freedom}

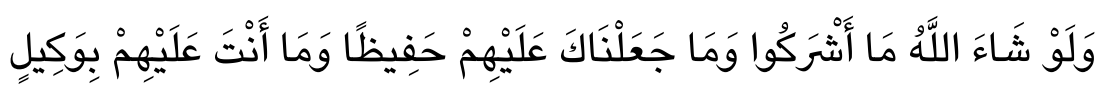

"If it had been God's will, they would not have done so, but We have not made you their guardian, nor are you their keeper" (Q.S. al-An'âm [6]: 107).

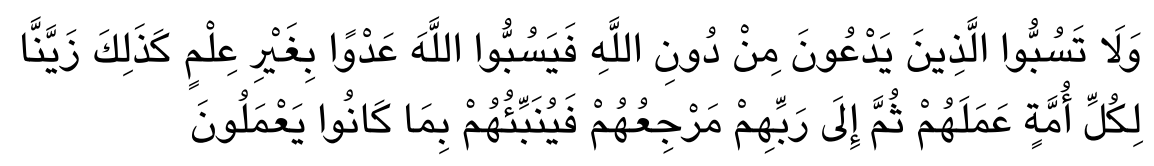


"[Believers], do not revile those they call on beside God in case they, in their hostility and ignorance, revile God. To each community We make their own actions seem alluring, but in the end they will return to their Lord and He will inform them of all they did" (Q.S. al-An'âm [6]: 108).

Q.S. al-An'âm [6]: 107-108 implicitly convey that if Allah had intended to make all living creatures on earth worship Him, so be it. However, that is not His will to make these creatures find their ways to be aware of themselves and the greatness and power of Allah (Hosen 2019a, 87). In his interpretation of al-Ma'idah [5]: 29, Shihab states that one of God's gifts to mankind is freedom. Therefore, it is very unfortunate if in reality there are Muslims who do not hesitate to insult others, make fun of their beliefs, and even force others to convert to Islam (Shihab 2019). These practices do not only cause disharmony between religions, but also have a negative impact on the internal Muslims themselves. Those who feel insulted by their religion will react and respond to the insult, and it is often addressed to Allah. It is ironic that because of this improper way of preaching and telling the truth, God became the object of humiliation.

The two verses above can be reflected as an answer to a phenomenon developing in Indonesia. Especially in a context where one of the religious leaders and a leader of Islamic mass organization, Rizieq Shihab, was able to deliver a lecture that allegedly contained elements of defamation against non-Muslims (BBC 2016). His statement drew negative responses from various parties, especially non-Muslims who in this matter were voiced by the central leadership of Perhimpunan Mahasiswa Katolik Republik Indonesia (PMKRI) who considered their religion to be insulted. Finally, they do not hesitate to criticize this figure, especially through social media which is directly aimed at Islam itself.

Allah in Q.S. al-Baqarah [2]: 256 says:

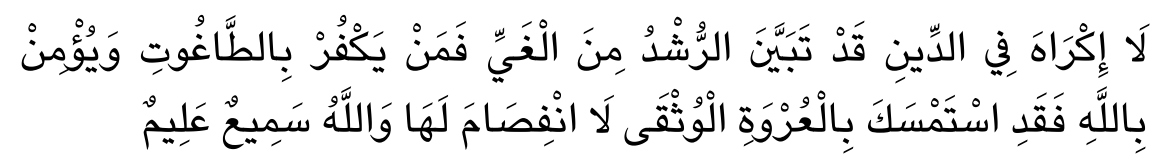

"There is no compulsion in religion; true guidance has become distinct from error, so whoever rejects false gods and believes in God has grasped the firmest hand-hold, one that will never break. God is all hearing and all knowing." 
In line with al-An'am [6]: 107-108, the above verse also shows that Islam does not justify compulsion in religion (Hosen 2019a, 89). If an individual deliver his da'wah message through the proper way, gently and politely, he/she would receive respect and grow reputation amongst his/her community. Accordingly, he/she would not need to emphasize the truth claim of the religion, although every religious community inevitably recognizes exclusive truth within their faith. If indeed Islam is the truest religion, it would be nice if it was not conveyed verbally directly but was applied in daily life by its adherents in a peaceful and respectful behaviour.

Although in fact al-Baqarah [2]: 256 still has various interpretations, some commentators state that the context of "Lâa ikrâha fî al-dîn" has been interpreted as a verse of war, resulting in different meanings in the interpretation of this verse. With the use of the context of the verse of war in the time of the prophet, the law of this verse also seems obligatory and compelling. However, there are also many interpretive scholars who oppose this opinion and explain the virtues of peaceful methods without coercion when preaching. In the sense that freedom of religion applies in normal or peaceful conditions, while the verse of war applies in situations of defending the aqidah (creed) of the people from opponents of Islam who take up arms first.

\section{Non-Muslim Leadership Issue}

Let us recall an outburst coming from a particular speech of the former Governor of DKI Jakarta, Basuki Tjahaja Purnama, that was eventually considered blasphemy. The controversy was rooted from a view rejecting non-Muslim leadership in Indonesia. A Quranic verse, i.e. alMâ'idah [5]: 51, was widely referred to by proponents of this view, attempting to advocate their position. In his speech, the former governor clearly insinuated and at the same time advised the public not to overly trust people who always herald the verse, especially during the last election campaign moment. This phenomenon suddenly gave rise to various kinds of resistance from various parties, especially Muslims. Finally, because of his speech, he was imprisoned for approximately two years to pay for his act.

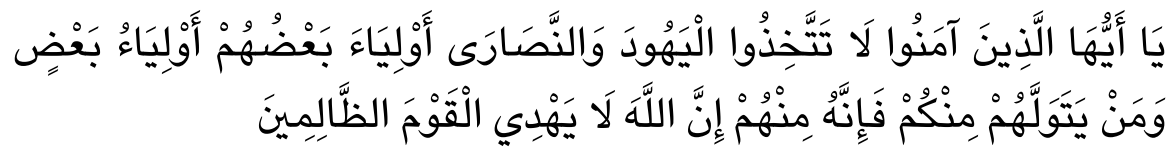


"You who believe, do not take the Jews and Christians as allies; they are allies only to each other. Anyone who takes them as an ally becomes one of themGod does not guide such wrongdoers" (Q.S. al-Mâ'idah [5]: 51).

According to Hosen, the word awliyâ mentioned in the verse cannot be used as an excuse not to choose a leader from non-Muslim community. This view is based on some classical commentaries he had consulted, suggesting that the meaning of the word awliy $\hat{a}$ ' is not the leaders but rather the allies (Hosen 2019a, 97). To be convincing, he provides a deeper explanation by presenting explanations on al-Mâ'idah [5]: 51 from a number of commentary books to suggest that the verse cannot be taken literally to mean the leaders.

In addition, he also mentions another verse in which the mentioned word awliyâ ' does not mean the leaders, namely al-Nisâ' [4]: 138-139. Hosen states that he has not found one single commentary books explaining the word awliyấ in these verses to signify for the leaders (Hosen 2019a, 113). In the end, it is evident that the verses that have been employed by several parties to support their political interests-such as in regional or national elections-are irrelevant, because these verses have nothing to do with the voting for the election candidate.

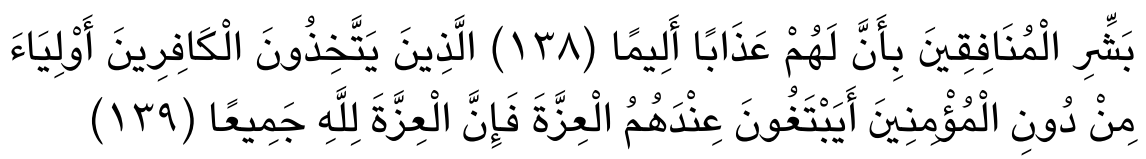

"[Prophet], tell such hypocrites that an agonizing torment awaits them. Do those who ally themselves rather than the believers seek power through them? In reality all power is God's to give" (Q.S. al-Nisâ' [4]: 138-139).

Unlike the message of the previous verses, Q.S. al-Mumtahanah [60]: 1 suggests a different meaning. It prohibits muwâlat al-kuffâr, which means to convey loyalty and affection to unbelievers (Hosen 2019a, 120). In this case, such prohibition is based on a particular context of hostile relationship between Muslims and infidels during the life of the prophet Muhammad, in which one of the Muslim soldiers was actually working with the enemy. Due to this incident al-Mumtahanah [60]: 1 was revealed, asserting that Muslims should not become the helper for infidels and to leave Muslims. 


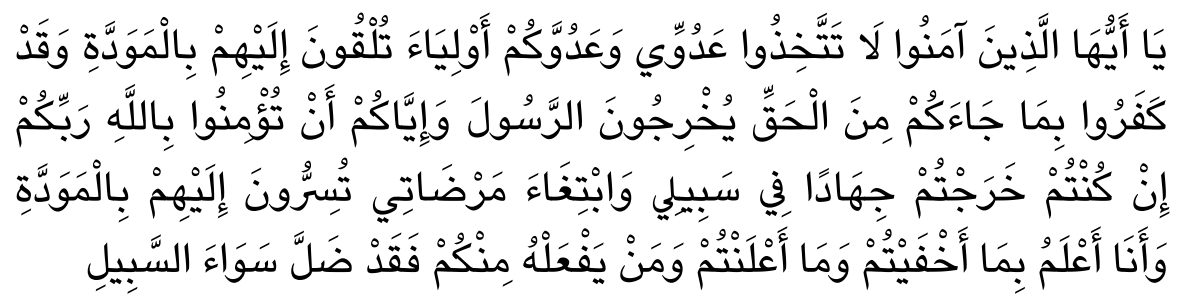

"You who believe, do not take My enemies and yours as your allies, showing them friendship when they have rejected the truth you have received, and have driven you and the Messenger out simply because you believe in God, your Lord-not if you truly emigrated in order to strive for My cause and seek My good pleasure. You secretly show them friendship-I know all you conceal and all you reveal-but any of you who do this are straying from the right path" (Q.S. al-Mumtahanah [60]: 1).

With regards to uli al-amr, there are various views from Quran commentaries. One view considers uli al-amr means scholars and umarâ' (leaders), the other views it points exclusively to Abû Bakr and 'Umar ibn alKhattâb, the other suggests that it means exclusively scholars, and one last view interprets the term as war commanders (Hosen 2019a, 137).

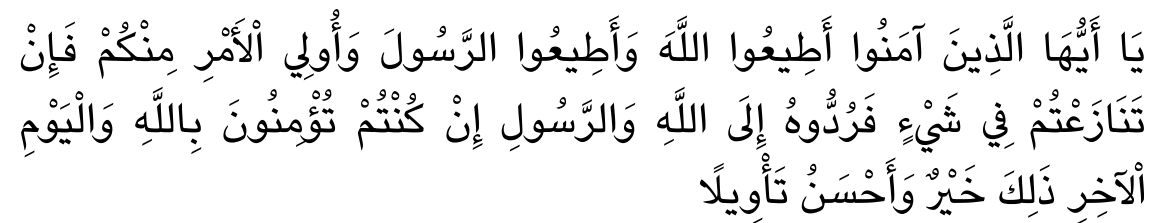

"You who believe, obey God and the Messenger, and those in authority among you. If you are in dispute over any matter, refer it to God and the Messenger, if you truly believe in God and the Last Day: that is better and fairer in the end" (Q.S. al-Nisâ' [4]: 59).

To date, the interpretation of uli alamr is a matter of debate. Accordingly, it is expected for the academics to be wise in dealing with this problem. Regardless of the diverse opinions regarding uli al-amr, it should be noted that the concept of obedience to the legitimate leader is indeed recommended in Islam and there are different levels of obedience between that towards God, the messenger, and the leaders. Therefore, according to Hosen, the concept of "obeying" is intentionally not clarified because it will 
always follow the subject to be obeyed. However, in the context of being obedient to the leaders, it is not an absolute compulsory, depending on whether the leadership in question is justified or not.

\section{Respond to Kafir Terms}

The blasphemy issues, the killing of non-Muslims under the label of jihâd, and dissonances between neighbours of different religions that divide the unity of society in Indonesia, are just a few examples of the results of hatred against a segment in community portrayed as 'kâfir'; a term which is often misused by certain people by using the following verses.

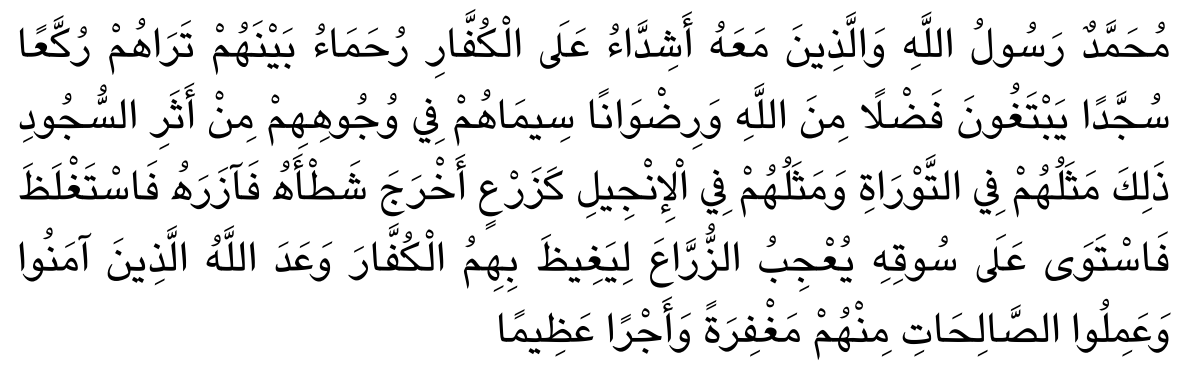

"Muhammad is the Messenger of God. Those who follow him are harsh towards the disbelievers and compassionate towards each other. You seem them kneeling and prostrating seeking God's bounty and His good pleasure: on their faces they bear the marks of their prostrations. This is how they are pictured in the Torah and the Gospel: like a seed that puts forth its shoot, becomes strong, grows thick, and rises on its stem to the delight of its sowers. So god infuriates the disbelievers through them; God promises forgiveness and a great reward to those who believe and do righteous deeds" (Q.S. al-Fath. [48]: 29)

In fact, the verse was also revealed in a tense situation of the Hudaybiyah agreement. Accordingly, it is evident that the current peaceful Indonesia is a different context, making the use of that verse irrelevant. Hence, Allah continues his clarification in the following verse:

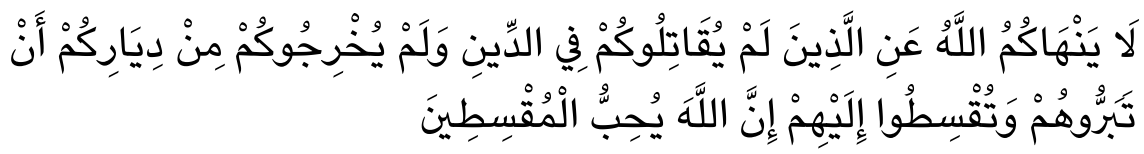


"And He does not forbid you to deal kindly and justly with anyone who has fought you for your faith or driven you out of your homes: God loves the just" (Q.S. al-Mumtahanah [60]: 8)

At this point, it can be understood that Allah does not forbid Muslims to do good to non-Muslims. This verse was a protection from Allah for the Prophet Muhammad when facing the disbelievers in the Hudaybiyah agreement even though there had been no resistance. This is in line with the viewpoint of Fikriyati and Fawaid regarding Pop-Tafsir which provides the view that in building social humans, one must treat others as equal humans so as to produce philosophical words: "There is nothing worthy of judging and labeling another, but Allah" (Fikriyati and Fawaid 2020).

\section{Quranic Verses Related to the KPU}

KPU (Komisi Pemilihan Umum, The Election Committee) announced the result of the election at the early hours. Some people consider this to be a conspiracy (Radar Malang 2019). They used the following verse to claim their guess.

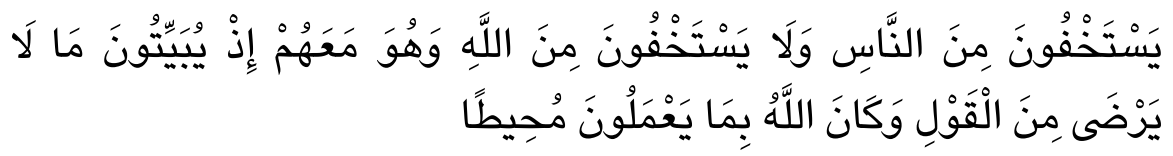

"They try to hide themselves from people, but they cannot hide from God. He is with them when they plot at night, saying things that do not please Him: He is fully aware of everything they do" (Q.S. al-Nisâ' [4]: 108).

Similar to the previous political verses, this verse also has no relation to what the KPU did. The occasion of the revelation of the verse shows that it actually dealt with the Quranic defence of an innocent Jew who was trapped in a conspiracy from evil Muslims.

\section{The Issue of Khilâfah (Caliphate)}

The drive to re-establish an Islamic State has long been echoed by some radical Islamists who want a return to the system considered applied during the time of the Prophet. Against this backdrop, after the dissolution of one of the organizations considered a hotbed of radicalism, the khilaffah discourse emerges in social media, especially Instagram. Some accounts 
affiliating to this radical movement transformed themselves into popular Islamic accounts that typically present Islamic religious contents to cover up their actual identities. This situation, according to Juwantara, have hardened into characters that are formed from the results of internalization of various beliefs as a basis for perspective, thought, behaviour, and act (Juwantara 2019, 161). Unfortunately, there is not a single verse in the Quran that promises a return to the rule of the khilâfah (Hosen 2019a, 171). Most of the commentators are of the opinion that the caliphate referred to in this verse was fulfilled at the time of the Prophet and was only limited to that period, although there are still others who believe in the coming of a khilâfah in the future.

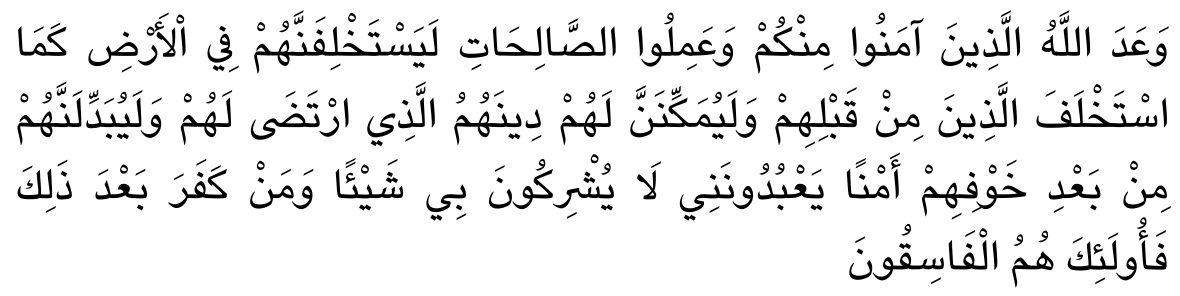

"God has made a promise to those among you who believe and do good deeds: He will make them successors to the land, as He did those who came before them; He will empower the religion He has chosen for them; he will grant them security to replace their fear. 'They will worship Me and not join anything with Me.' Those who are defiant after that will be the rebels" (Q.S. al-Nûr [24]: 55).

\section{Tafsir al-Qur'an di Medsos: A Media of Resistance}

The presence of the Tafsir al-Qur'an di Medsos is a form of resistance towards the dynamics and phenomena of contemporary Muslim diversity, especially in the Indonesian context. The object of resistance chosen by Nadirsyah Hosen was the Quran's interpretation coming from certain groups with certain interests, especially political interests. There are several topics that Hosen chooses as the analysis object, ranging from issues of religion's freedom or belief, non-Muslim leadership to verses that are claimed to support the caliphate.

Through Tafsir al-Qur'an di Medsos, it seems that Hosen wants to emphasize that some of the interpretations currently circulated in this political space need to be given more serious attention. The problem is not only related to differences in interpretation, but also to the level of 
distorting the Quran itself as a book of mercy, guidance and so on. Politicaltendentious interpretations, as seen in the growing discourse, in turn have complex implications, especially in the socio-practical context, such as creating divisions between the citizens, in particular, and ultimately disrupting the stability of the life of the nation and state in general.

There is a unique model and method taken by Hosen through this work, namely negotiating between the attempts to restore the authoritative interpretive views provided by classical commentaries and to make these commentaries relevant to contemporary life, especially for the Indonesian context. What he considered authoritative interpretive views are those coming from the 'ulamâ' who are well-known as mufassir (interpreter). Of course, his attempts are also supported by the use of scientific instruments recognized in the world of Quran's interpretation in particular and the world of Islam in general.

Apart from the phenomena and dynamics working at the background of Tafsir al-Qur'an di Medsos, there is one problem that has not received much attention, namely the issue of authority and textual. These acts of politicization of the Quran, with its various forms and interests, indicate that the Quran is still believed to have authority. Nevertheless, the interpreters do not have the same authority. This means that the emergence of various interpretations made by the general public indicates that they also feel they have the right to interpret the Quran. This phenomenon is also a sign that the interpretive authority that was typically attached to religious elite figures seems to have shifted by itself (Lukman 2018).

As the general public, their interpretation appears to be undergoing a process of simplification (Al Qurtuby 2018; Kurniawan 2018). By simplification, we mean the interpretation neglect aspects or scientific instruments that are usually attached as prerequisite for interpreting the Quran. The simplification model is how to interpret the Quran, then, it is as close as possible to the impression of a credible interpretation. The real implication of such an interpretive model is the re-strengthening of authoritarianism in interpretation.

Of course, this phenomenon is a problem in the discourse of the Quranic interpretation, and therefore, an effort is needed to counter the problem. In this case, Hosen gave an overview of how to understand the verses that were politicized proportionally. The verses of the Quran must be interpreted by referring to the explanation of the earlier scholars. It is, however, inadequate; it must also be properly contextualized in social life. 


\section{Conclusion}

The emergence of new media has resulted in a shift in socio-religious phenomena in society. Religious values that were previously considered sacred have indirectly been eroded into baseless forms of misuse in the political atmosphere in order to gain instant power. This is dangerous for society, especially in Indonesia which is home to religious communities. In this case, Hosen resists against the dynamics and phenomena of contemporary Muslim diversity, especially in the Indonesian context. $\mathrm{He}$ interprets the Quran as a counteract to the politicization of the Quran through social media platforms, especially in relation to the Indonesian political situation. He tries to affirm that tafsir should refer to credible literature and that the Quran must be understood in a proper context.

According to Nadirsyah Hosen, Islam does not justify coercion in religion. The religious freedom verses, i.e. al-An'âm [6]: 108 and al-Baqarah [2]: 256, apply in normal and peaceful circumstance, whereas the war verse applies specifically in situations of maintaining aqidah (creed) and upholding peace through non-coersive preaching. For the Quranic labeling of kâfir and kâfir leadership issue, one cannot use the verses as an excuse to not choosing leaders from non-Muslims figures, because Allah does not forbid Muslims to do good to non-Muslims according to al-Mumtahanah [60]: 8. In addition, the interpretation that links al-Nûr [24]: 55 with the attempts at establishing an Islamic state is considered inappropriate, because this condition was fulfilled at the time of the Prophet which was different from the present. Associating al-Nisâ' [4]: 108 to the KPU issue is inaccurate, because the occasion of the verse's revelation indicates the Quran's defense of an innocent Jew who trapped in a conspiracy from a Muslim.

\section{References}

Achmad, Noor. 2018. "Politisasi Agama di Era Digital dan Penanganannya.” Proceeding Senaspolhi 1(1): 141-45.

Ali, Hasanuddin, Lilik Purwandi, and Moh. Firmansyah. 2015. The Potraits of Urban Moslem Indonesia. Jakarta Selatan: Alvara Research Center.

Al Qurtuby, Sumanto. 2018. "Sejarah Politik Politisasi Agama dan Dampaknya di Indonesia." Maarif Journal 13(2): 43-54. 
DOI: https://doi.org/10.47651/mrf.v13i2.21

BBC. 2016. "'Rizieq Shihab Dilaporkan Ke Polisi, Dituduh Lecehkan Umat Kristen,' BBC News Indonesia, December 26, 2016, Bag. Indonesia, https://www.bbc.com/Indonesia/Indonesia-38435195."

Dawson, Lorne L., and Douglas E. Cowan, eds. 2004. Religion Online: Finding Faith on the Internet. London: Rouledge.

Duarte, Fernando. 2019. “'Berapa Banyak Waktu Yang Dihabiskan Rakyat Indonesia di Media Sosial?,' BBC News Indonesia, September 9, 2019, Bag. Majalah, https://www.bbc.com/Indonesia/Majalah49630216.”

Fikriyati, U, and A Fawaid. 2020. "Pop-Tafsir on Indonesian YouTube Channel: Emergence, Discourses, and Contestations." In Proceeding of the 19th Annual International Conference on Islamic Studies, AICIS 2019. Jakarta, October 1-5, 2019. EAI.

DOI: http://dx.doi.org/10.4108/eai.1-10-2019.2291646

Hakim, Lukman. 2013. "Arus Baru Feminisme Islam Indonesia dalam Film Religi.” Jurnal Komunikasi Islam 03(02): 251-67.

DOI: https://doi.org/10.15642/jki.2013.3.2.250-267

Hosen, Nadirsyah. 2019a. Tafsir Al-Qur'an di Medsos: Mengkaji Makna dan Rahasia Ayat Suci Pada Era Media Sosial. Yogyakarta: Bentang Pustaka.

Hosen, Nadirsyah. 2019b. "Gus Nadir Sebut Politisasi Al-Quran sebagai Penyakit Klasik Umat Islam.” accessed March 1, 2020. https://www.nu.or.id/post/read/111654/gus-nadir-sebut-politisasi-al-quransebagai-penyakit-klasik-umat-islam.

Imron, Ali. 2019. "The Millenial Generation, Hadith Memes, and Identity Politics: The New Face of Political Contestation in Contemporary Indonesia." Ulul Albab: Jurnal Studi Islam 20(2): 255-83.

DOI: https://doi.org/10.18860/ua.v20i2.5675

Juwantara, Ridho Agung. 2019. "Efektivitas Ekstrakurikuler Pramuka dalam Menanamkan Karakter Jujur Disiplin dan Bertanggung Jawab Pada Siswa Madrasah Ibtidaiyah." Premiere Educandum: Jurnal Pendidikan Dasar dan Pembelajaran 9(2): 160-71.

DOI: http://doi.org/10.25273/pe.v9i2.4994 
Kholiludin, Tedi. 2016. "Islamisme, Pos-Islamisme dan Islam Sipil: Membaca Arah Baru Gerakan Islam'.” Jurnal Iqtisad 3(1): 52-64.

DOI: http://dx.doi.org/10.31942/iq.v3i1.2460

Kietzmann, Jan H., Kristopher Hermkens, Ian P. McCarthy, and Bruno S. Silvestre. 2011. "Social Media? Get Serious! Understanding the Functional Building Blocks of Social Media." Business Horizons 54(3): 241-51.

DOI: https://doi.org/10.1016/j.bushor.2011.01.005

Kominfo, PDSI. 2018. "'Angka Penggunaan Media Sosial Orang Indonesia Tinggi, Potensi Konflik Juga Amat Besar,' website Kementerian Komunikasi dan Informatika RI, accessed March 4, 2020, https://kominfo.go.id:443/Content/Detail/14136/Angka-

Penggunaan-Media-Sosial-Orang-Indo.”

Krysinska, Karolina, Karl Andriessen, and Jozef Corveleyn. 2014. "Religion and Spirituality in Online Suicide Bereavement: An Analysis of Online Memorials." Crisis 35(5): 349-56.

DOI: $10.1027 / 0227-5910 / \mathrm{a} 000270$

Kurniawan, Budi. 2018. "Politisasi Agama di Tahun Politik: Politik PascaKebenaran di Indonesia dan Ancaman Bagi Demokrasi." Jurnal Sosiologi Agama 12(1): 133-54.

DOI: https://doi.org/10.14421/jsa.2018.121-07

Leege, David C., and Lymann A. Kellstedt. 1993. Rediscovering The Religious Factor in American Politics. United States: ANSI.

Lengauer, Dayana. 2018. "Sharing Semangat Taqwa: Social Media and Digital Islamic Socialities in Bandung." Indonesia and the Malay World 46(134): 5-23.

DOI: https://doi.org/10.1080/13639811.2018.1415276

Lukman, Fadhli. 2018. "Digital Hermeneutics and A New Face of The Qur`an Commentary: The Qur`an in Indonesian`s Facebook.” AlJami'ah: Journal of Islamic Studies 56(1): 95-120.

DOI: https://doi.org/10.14421/ajis.2018.561.95-120

Mahfudh, MA. Sahal. 1994. Nuansa Fiqih Sosial. Yogyakarta: LKiS.

Manuel Castells, and Gustavo Cardoso, eds. 2005. The Network Society from 
Knowledge to Policy, Center for Transatlantic Relations. Washington DC: The Johns Hopkins University.

Miladi, Noureddine. 2016. "Social Media and Social Change." Digest of Middle East Studies 25(1) (Spring 2016): 35-51.

Miski, Miski. 2017. "Fenomena Meme Hadis Celana Cingkrang dalam Media Sosial." Harmoni 16(2): 291-306.

DOI: https://doi.org/10.32488/harmoni.v16i2.7

Miski, Miski, and Ali Hamdan. 2019. "Alqur'an dan Hadith dalam Wacana Delegitimasi Nasionalisme di Media Online Islam.” Al-A'raf: Jurnal Pemikiran Islam dan Filsafat 16(1): 25-46.

DOI: https://doi.org/10.22515/ajpif.v16i1.1644

Muhtador, Moh. 2018. "'Pentingnya Asbabun Nuzul dalam Memahami AlQur'an,' accessed March 4, 2020, https://islam.nu.or.id/Post/Read/93669/Pentingnya-AsbabunNuzul-Dalam-Memahami-Al-Quran.”

Mulawarman, Mulawarman, and Aldila Dyas Nurfitri. 2017. "Perilaku Pengguna Media Sosial Beserta Implikasinya Ditinjau dari Perspektif Psikologi Sosial Terapan.” Buletin Psikologi 25(1): 36-44.

DOI: https://doi.org/10.22146/buletinpsikologi.22759

Muzakka, Ahmad Khotim. 2018. "Otoritas Keagamaan dan Fatwa Personal di Indonesia." Epistemé: Jurnal Pengembangan Ilmu Keislaman 13(1): 6388.

DOI: https://doi.org/10.21274/epis.2018.13.1.63-88

Ogunto, Danoye Oguntola. 2008. "Religion and Politics in A Pluralistic Society: The Nigerian Experience." Journal Politics and Religion-Politologi Des Religion 2(2): 123-29.

Omar, Faradillah Iqmar, Hazlin Falina Rosli, Nurzakira Afnee Zakaria, and Nuraina Nabila Dundai Abdullah. 2015. "Hubungan Penggunaan Media Sosial dan Penerimaan Mesej Dakwah." In Proceeding of the 2nd International Conference on Management and Muamalah 2015: 181-91. http://www.kuis.edu.my/icomm/2nd/download/IC 013.pdf.

Onapajo, Hakeem. 2012. "Politics for God: Religion, Politics and Conflict in Democratic Nigeria,." The Journal of Pan African Studies (4)9: 42-50. 
Pink, Johanna. 2010. "Tradition and Ideology in Contemporary Sunnite Qur'ānic Exegesis: Qur'ānic Commentaries from the Arab World, Turkey and Indonesia and Their Interpretation of Q 5:51.” Die Welt des Islams 50(1): 3-59.

Pradana, Henry, and Nova Yuliati. 2015. "Nilai-Nilai Islami dalam Film Cinta Subuh." In Prosiding Hubungan Masyarakat, Bandung: Fakultas Ilmu Komunikasi UNISBA, 109-16.

Radar Malang. 2019. "'Hasil Rekapitulasi KPU Disangkutkan Dengan AnNisa 108, MUI Malang Bereaksi,.” https://radarmalang.id/hasilrekapitulasi-kpu-disangkutkan-dengan-an-nisa-108-mui-malangbereaksi/.

Rifauddin, Machsun. 2016. "Fenomena Cyberbullying Pada Remaja (Studi Analisis Media Sosial Facebook)." Khizanah al-Hikmah: Jurnal Ilmu Perpustakaan, Informasi, dan Kearsipan 4(1): 35-44.

DOI: https://doi.org/10.20961/jpi.v4i1.33796

Saifullah, Muhammad. 2019. "Hermeneutika Al-Quran Virtual: Kajian Atas Penafsiran Al-Qur'an Nadirsyah Hosen di Facebook, Twitter, Telegram, dan Website.” MA Theses. Universitas Islam Negeri Sunan Kalijaga Yogyakarta.

Sharifian, Ehsan, Mohammadreza Pourjafar, and Ali Akbar Taghvaee. 2017. "An Analysis of 'City' and 'Urbanization' Concept According to Quran's Perspective." Hoviatshahr 11(1): 53-66.

Shihab, Quraish. 2019. Islam Yang Saya Pahami: Keragaman Itu Rahmat. Tangerang: Lentera Hati.

Slama, Martin. 2018. "Practising Islam through Social Media in Indonesia." Indonesia and the Malay World 46(134): 1-4.

DOI: https://doi.org/10.1080/13639811.2018.1416798

Tibi, Bassam. 2012. Islamism and Islam. Yale: Yale University Press.

Tibi, Bassam. 2016. Islam dan Islamisme. Trans. Alfathri Adlin. Bandung: Mizan Pustaka.

Turner, Bryan S. 2011. Religion and Modern Society: Citizenship, Secularisation, and the State. United Kingdom: Cambridge University Press.

Zuhri, Saifuddin, Moh Hidayat Noor, and Miski. 2018. "Komunitas Online 
www.arrahmah.com serta Seruan Kembali Pada Al-Quran dan Hadis: Identitas, Ideologi, dan Imaji Fundamentalisme." In Ancoms: 2nd Annual Conference for Muslim Sholars, 144-60. 